\title{
EMPIRE RHEUMATISM COUNCIL
}

\author{
LORD HORDER'S SECOND ANNUAL REPORT \\ (November, 1937, to November, 1938)
}

Presented to and Accepted by the Annual Meeting held on Monday, December 19, 1938.

IT is again my privilege and duty to present to you the Annual Report of the Empire Rheumatism Council, and to chronicle our progress in the war against rheumatic disease for the past year.

Disclaiming any need to be apologetic-for the progress has been remarkable-yet I ask leave to remind you that the period under review has been a most difficult one in every department of our work. The education of the public in regard to rheumatic disease met the obstacle of grave preoccupation with gas masks and bomb-proof shelters. Appeals for funds for our work of research and the promotion of treatment centres were made under conditions of an almost general decline of the resources of the charitable, and had to face the competition of several pressing appeals which man's inhumanity to man had made necessary. The building of our temple, figuratively speaking, had to be carried on with the sword in one hand, the trowel in the other.

At one period of serious anxiety, indeed, we faced the possibility of having to interrupt our work, or a great part of it, for the duration of a war; and to put to the decision of the national authorities as to what should be suspended and what continued. You will be pleased to know that if that contingency had actually arisen we had ready plans which would have fallen in with the national interests and would have safeguarded our funds against wastage until interrupted tasks could be resumed under happier conditions.

I wish to acknowledge again the generous co-operation of the Press in our educational work. In spite of other demands on their columns, favourable attention has been given to our many efforts to arouse public interest to the great gap in our national health defence system which exists in the former neglect of rheumatic disease. 
With thankfulness we note the recent wise decision of the Government in regard to the treatment of cancer, and express the confidence that, with the growth of knowledge of the tragic degree of human suffering and economic loss caused by rheumatism, this will also shortly be fully recognised as a national problem. Meanwhile the voluntary effort which our Council has undertaken needs to be carried on with persistent vigour.

\section{Organisation}

The formation of an affiliated Council in Canada was noted last year. This year favourable progress has been made in the foundation of an Australian Council. Several conferences with representative medical men of that Dominion have been held, and the support of the Australian Medical Press assured. We learn that a forthcoming Medical Congress in our southern continent will devote its attention exclusively to the problems of rheumatic disease, and it is planned that this occasion will be taken for the foundation of an Australian Rheumatism Council.

In Scotland there has been good progress; and in provincial centres there are to be noted movements to strengthen the research and treatment resources of two of our great British spas.

Since our last meeting the Central Council has gained someot notable additions to its ranks, as the list following this report shows. It will be noted that the dental profession is now well represented on this body.

You will be called upon to elect for the coming year officers and members of the committees entrusted with the various departments of the Council's work. Your Executive Committee have made recommendations regarding these officers and committee members; but it is within your power to propose alternative nominations, and decisions rest with the members of the Council.

The various committees have carried out their duties during the year with zeal, and members have met cheerfully the heavy demands entailed on their time. The Scientific Advisory Committee, in order to deal more promptly with the very great amount of work coming before it, has decided to form three sub-committees (Bacteriological, Chemical and Physical) to give preliminary examination to (and in some cases tests of) suggestions for treatment, new and old. The Research Advisory Committee has given careful attention to its most important 
task of giving recommendations in regard to Research Grants and Research Fellowships. We are greatly indebted to the Medical Research Council for assistance in this matter. If some applicants have experienced disappointment from postponement or refusal of their applications they must not consider that as implying a criticism of the value of their proposals; they should rather ascribe it to the fact that the Research Advisory Committee must endeavour to follow a "policy" of research and give preference to what seems of more immediate importance. The Finance Committee maintains a constant watchfulness on our funds, and takes care that we shall enter into no commitments for which there is not adequate provision.

The administrative work of the Council has increased greatly with the growth of our research and other tasks, but the increase has been dealt with admirably by our staff.

\section{Regsearch into Causes}

The work of research undertaken by the Council is growing. The most recent and important part of this is the undertaking to set up, in co-operation with the Admiralty, a Research Foundation to investigate the causes and the best means of prevention and treatment of rheumatic disease in the training establishments of the Royal Navy. Up to the first decade of this century rheumatism was a considerable problem in H.M. ships. It is now rare among trained seamen; the success in overcoming it is probably due to the improvement of the medical services and the living accommodation. In the training establishments, however, the position cannot yet be considered entirely satisfactory. The Medical Service of the Admiralty and the Medical Staff of the naval hospitals and laboratories will assist fully the Empire Rheumatism Council in its investigation.

We recognise the importance of this task, not only as a service to the principal line of defence of the realm, but as a highly promising opportunity of solving one of the chief problems of the causation and treatment of rheumatic disease. There will be opened up a wide field of research among a great number of youths, all of the same age group, all under disciplinary control and subject to medical observation over a long period. Dr. C. A. Green, who has a distinguished research record, comes from the Bacteriology Department of Edinburgh University to take 
direct charge of the Foundation. A special ad hoc sub-committee consisting of Sir William Willcox, Professor Geoffrey Hadfield, Dr. Mervyn Gordon, Dr. W. S. C. Copeman and myself will supervise the work generally. The Sir Halley Stewart Trust has generously granted Dr. Green a Research Fellowship for three years to assist in this task. Every factor in the problembacteriological, biochemical and environmental-will be investigated at the chief naval training establishments.

Both the Alexander Maclean Research Laboratories-at the St. John Clinic and at the Hospitals of St. John and St. Elizabeth -are now in active work.

Research grants have been approved to:

Professor H. Woollard, University College, London (two grants-for research into the age changes in the weightbearing joints, and into the pathology of fibrositis).

Dr. E. H. Koerner, Guy's Hospital, London (research into chronic rheumatoid arthritis).

Dr. Cecilia Lutwak-Mann, University of Cambridge (research into the biochemistry of the joints).

The Hospital of St. John and St. Elizabeth, London (research into occupational therapy in rheumatic disease).

Two of these grants were made out of the funds put at our disposal by the Giff-Edmonds Trust.

\section{Problems of Treatment}

The second objective of your Council, research into the best means of treatment, has had concurrent attention.

A generous gift of Sir Alexander Walker enabled the Council to appoint Dr. W. S. Tegner as a Travelling Scholar to visit the chief treatment centres of Europe and the Eastern United States and report on their systems of treatment. He began his work on June 7, 1938, and will complete it early next year.

Another Travelling Scholar, Dr. J. J. R. Duthie, is making a special study of the system of treatment of Dr. Swaim of Boston on behalf of the Scottish branch of our movement.

The task of preparing a report on a system of treatment which might be economically applicable to a large number of sufferers, and even possible of application on a national scale, is actively proceeding. It is anticipated that this report will be completed during the first quarter of the New Year. 
In the promotion of new treatment centres there has been some good progress. If that progress were stated in percentage terms of advance it would be impressive; stated in numbers it would not seem so striking. The fact is that on the date when our Council began its work the number of institutions with special departments for the treatment of rheumatic disease was very small. An investigation showed that of the great hospitals associated with University Medical Schools the majority had no specialised clinics for rheumatic disease; of all the hospitals in the kingdom, numbering over one thousand, less than fifty had special Rheumatism Departments, though of course all, or nearly all, treated rheumatic patients. Accepting as a fact-and it is safe to do so-that the vast majority of rheumatic sufferers have little chance of cure or of real improvement without special treatment, it can be estimated that specialised treatment is available for less than 10 per cent. in the case of adults; for less than 25 per cent. in the case of juveniles. It has been estimated that there are over a million adult sufferers in England and Wales, and about half a million juvenile sufferers.

Since this matter of treatment will be more fully dealt with in the report mentioned in the previous paragraph, I shall not refer to it further now, except to express the grateful appreciation of the Council to those municipal bodies, voluntary hospitals and other institutions which have come to our aid during the year in establishing, or helping to establish, new treatment centres.

\section{The Funds of the Council}

During the year new subscriptions and promises under bond or other definite undertaking fell slightly short of doubling the amount gathered in the previous year. In all the circumstances it is not a discouraging result. We hope that the current year will be better, and that the Public Appeal (fixed for 1938, but unavoidably postponed) will reap a good harvest. To those with disposable wealth it may be suggested that it is not wise to be over-anxious for the future; and that gifts to a good cause bring in priceless dividends of human happiness and in no circumstances can depreciate in value. 
Supplementing his report for 1938, Lord Horder announced that in 1939 the Empire Rheumatism Council would begin publication of an official journal. This would continue, and extend in scope, the "Reports on Chronic Rheumatic Diseases," hitherto published by the British Committee on Chronic Rheumatic Diseases of the Royal College of Physicians. That body had decided that its task was completed with the formation of the Empire Rheumatism Council, and therefore had dissolved. The Council was invited to take, and accepted, the responsibility of continuing the publication of its "Reports on Chronic Rheumatic Diseases." In January would begin publication of a new series, The Rheumatic Diseases, under the able editorship of Dr. Buckley, Dr. Copeman and Mr. Timbrell Fisher.

The Finance Committee's report, presented by Mr. T. W. Robinson, and adopted, showed that the total amount made available for the Council's work up to October 31, 1938, was $£ 45,327$. Most of this was pledged for tasks undertaken, though an adequate reserve of unallocated funds had been maintained. At least $£ 100,000$ additional was needed to carry out the Council's programme. 